\title{
Paleomagnetic and rock-magnetic survey of Brunhes lava flows from Tancitaro volcano, Mexico
}

\author{
R. Maciel Peña ${ }^{*}$, A. Goguitchaichvili1 ${ }^{1}$, V. H. Garduño Monroy², V. C. Ruiz Martinez ${ }^{3}$, B. Aguilar \\ Reyes $^{1}$, J. Morales ${ }^{1}$ L. Alva-Valdivia ${ }^{4}$, C. Caballero Miranda ${ }^{4}$ and J. Urrutia-Fucugauchi ${ }^{4}$ \\ ${ }^{I}$ Laboratorio Interinstitucional de Magnetismo Natural, Instituto de Geofísica - Sede Michoacán, Universidad Nacional \\ Autónoma de México, Campus Morelia, Mexico. \\ ${ }^{2}$ Departamento de Geología y Mineralogía, Instituto de Investigaciones Metalúrgicas, Universidad Michoacana, San \\ Nicolás de Hidalgo, Morelia, Michyaoacán, Mexico. \\ ${ }^{3}$ Departamento de Física de la Tierra, Astronomía y Astrofísica I, Universidad Complutense de Madrid, Madrid, Spain. \\ ${ }^{4}$ Laboratorio de Paleomagnétismo y Geofísica Nuclear, Instituto de Geofísica, Universidad Nacional Autónoma de \\ México, Mexico City, Mexico.
}

Received: March 31, 2009; accepted: May 13, 2009

\section{Resumen}

Este estudio presenta los resultados paleomagnéticos del Volcán Tancitaro, (perteneciente al Campo Volcánico Michoacán Guanajuato), en el oeste de México, como una contribución a la base de datos de promediados en el tiempo del campo global. Se realizó el estudio paleomagnético y de magnetismo de roca en once flujos de lava. Se colectaron 120 núcleos orientados en el volcán Tancitaro y sus áreas aledañas. Todos los sitios fueron previamente fechados por ${ }^{40} \mathrm{Ar}{ }^{-39} \mathrm{Ar}$ (Ownby et al., 2007,) y van desde 793 ka hasta el presente. Se realizaron experimentos de magnetismo de roca, curvas de susceptibilidad e histéresis magnética y en la mayoría de los casos la remanencia magnética fue por la presencia de titanomagnetita pobre en Titanio con estructura magnética de pseudodominio simple. Ocho de los once flujos de lava dieron polaridad normal, mientras que los tres restantes produjeron paleodirecciones inconsistentes y no se tomaron en cuenta para el análisis y se debió probablemente por efectos de rayos. La paleodirección principal obtenida de los ocho flujos es Inc $=39.5^{\circ}$, Dec $=$ $356.4^{\circ}, \mathrm{k}=29, \alpha_{95}=9.1^{\circ}$ lo cual corresponde a la posición del polo con Plat $=84.4^{\circ}$, Plong $=219.9^{\circ}, \mathrm{K}=33$ y $\alpha_{95}=8.5^{\circ}$. Esta dirección es prácticamente consistente con la paleodirección esperada del Plio Cuaternario, derivada del polo de referencia para el Craton Norteamericano. La variación paleosecular coincide con otros estudios de la misma latitud y con modelos estadísticos recientes. La inclinación media cae dentro de la incertidumbre del Eje Dipolar Geomagnético más 5\% de contribuciones cuadrupolares.

Palabras clave: Paleomagnetismo, variación paleosecular, promedio de tiempo de campo, epoca Brunhes, Cinturón Volcánico Trans- Mexicano.

\begin{abstract}
This study presents paleomagnetic results from Tancitaro volcanism in the Michoacan Guanajuato Volcanic Field, western Mexico, as a contribution to the time averaged field global database. Detailed paleomagnetic and rock-magnetic studies were carried out on eleven independent lava flows; 120 oriented, standard paleomagnetic cores were collected from Tancitaro volcano and surrounding areas. All sites were dated by means of ${ }^{40} \mathrm{Ar}-{ }^{39} \mathrm{Ar}$ (Ownby et al., 2007) as originating from 793 ka to present. Rock-magnetic experiments included continuous susceptibility and hysteresis measurements. Remanence is carried mostly by Ti-poor titanomagnetite of pseudosingle-domain magnetic structure. Eight out of eleven flows yield normal magnetic polarities while three sites yielded inconsistent paleodirections most probably due to lightning. Mean paleodirection from eight flows is Inc $=39.5^{\circ}, \mathrm{Dec}=356.4^{\circ}, \mathrm{k}=29, \alpha_{95}=9.1^{\circ}$ which corresponds to a pole position with Plat $=84.4^{\circ}, \mathrm{Plong}=219.9^{\circ}$, $\mathrm{K}=33$ and $\mathrm{A}_{95}=8.5^{\circ}$, practically undistinguishable from expected Plio-Quaternary paleodirections, for the North American Craton. Paleosecular variation is compatible with other studies at the same latitude bands and with recent statistical models. The mean inclination falls within the uncertainties of the Geomagnetic Axial Dipole plus $5 \%$ quadrupolar contributions.
\end{abstract}

Key words: Paleosecular variation, time averaged field, Brunhes chron, Trans-Mexican Volcanic Belt. 


\section{Introduction}

Fluctuations of the geomagnetic field with time are essential for understanding the geodynamo, and conditions in the Earth's liquid core and at the core-mantle boundary. Paleosecular variation may indicate modulation of geodynamo action in the core by the convective state of the lower mantle. Thus, determinations of these variations are decisive for understanding the processes in the core that give rise to the geomagnetic field and how and why the Earth's magnetic field reverses polarity.

The fundamental factors in the variability of the Earth Magnetic Field are the Time Averaged Field (TAF) and paleosecular variation (PSV). The TAF initiative has begun to update the database of geomagnetic observations over the last five million years (Mejia et al., 2005; Tauxe et al., 2004, Lawrence et al., 2006; Lawrence et al., 2009). A simple method to estimate the PSV consists in observing of the angular standard deviation (ASD) of virtual geomagnetic poles (VGPs) for a given locality. Several combinations of dipole and non-dipole components predict the ASD characteristic of PSV with latitude (McFadden et al., 1988, 1991; Lawrence et al., 2006; Johnson et al. 2008)).

Johnson et al. (2008) reported a detailed synthesis of a new generation of paleomagnetic data compilations. The latitudinal dependence of VGP (virtual geomagnetic poles) scatter for these data appears much less important. The data at low latitudes seems to be more scattered than those at high latitude. This issue depends critically on a set of data of latitude $20^{\circ} \mathrm{N}$. Published directional data from Trans Mexican Volcanic Belt (TMVB) meeting some very basic selection criteria (Herrero-Bervera et al., 1986; Ruiz-Martinez et al., 2000; Osete et al., 2000, Morales et al., 2001, Alva-Valdivia et al., 2001; Mejia et al., 2005; Petronille et al., 2005, Rodriguez-Ceja et al., 2006) show an unusually high degree of scatter, which might be due to genuine geomagnetic field behavior.

The present study reports time averaged field global database and paleosecular investigations at low latitudes, based on a detailed rock-magnetic and paleomagnetic study of eleven lava flows associated to Tancitaro Volcano in the Michoacan Guanajuato Volcanic Field (MGVF). All sites were recently dated by means of $\mathrm{Ar}^{40}-\mathrm{Ar}^{39}$ systematics (Ownby et al., 2007). The available ages range from 793 Ka to present.

\section{Available age and sampling}

The Trans-Mexican Volcanic Belt contains stratovolcanoes, cinder cone fields and silicic caldera complexes. Volcanism in this region dates from late
Miocene related to the subduction of Cocos and Rivera plates at the Middle America trench. The western TMVB is associated with subduction of $\sim 9$ Ma Rivera plate, whereas the 12-18 Ma Cocos plate subducts under North America to the east (Klitgord and Mammerickx, 1982).

The Michoacan-Guanajuato volcanic field is located in the west-central part of TMVB (Fig. 1), east of Chapala Lake. The geographic boundaries of the MGVF are $18^{\circ} 45^{\prime} \mathrm{N}$ to $20^{\circ} 15^{\prime} \mathrm{N}$ and $100^{\circ} 25^{\prime} \mathrm{W}$ to $100^{\circ} 45^{\prime} \mathrm{W}$, with an area of $40,000 \mathrm{~km}^{2}$, It contains over 2,000 small monogenetic volcanoes including cinder cones $(90 \%)$, maars, tuff rings, lava domes and lava flows with hidden vents all are predominant calc-alkaline but some alkaline and transitional rocks are also found Silica content varies from $47 \%$ to $70 \%$ for olivine basalt and basalt-andesite rocks (Hasenaka, 1994; Hasenaka et al., 1994).

Volcán Tancítaro (VT) is a large andesitic, composite volcano in the Michoacán-Guanajuato Volcanic Field in west-central Mexico. With a height of $3840 \mathrm{~m}$ (Ownby et al., 2007), VT is the dominant feature in the MGVF. Twenty-six new $\mathrm{Ar}^{40}$ - $\mathrm{Ar}^{39}$ ages indicate that Tancítaro became active $\geq 793 \pm 22 \mathrm{ka}$ and that the most recent effusive activity occurred at $237 \pm 4 \mathrm{ka}$. Two catastrophic sector-collapse events are identified and dated; the first one on the west flank between 694 and $571 \mathrm{ka}$, and the second on the east flank between 261 and $238 \mathrm{ka}$ (Ownby et al., 2007).

Our sampling strategy was largely conditioned by Ownby et al. (2007) who gave 26 new Ar-Ar incremental heating ages for Tancitaro and adjacent sorounding areas. We sampled only sites with available radiometric dating information (Table 1 and Fig. 2 trough 4), of easy access and yielding fresh, apparently unanltered outcrops. In total, 120 oriented samples belonging to 11 individual lava flows were collected. The samples were distributed throughout each flow both horizontally and vertically. All lava flows sampled were horizontal (dip less than $4^{\circ}$ ). In general, samples were obtained at the bottom of flows with the hope of collecting samples with the finest grained material. Cores were sampled with a gasolinepowered portable drill, and oriented in most cases with both magnetic and sun compasses.

\section{Summary of magnetic experiments}

In order to obtain the directions of characteristic remanent magnetization and to identify the principal magnetic carriers, following experiments were carried out: a) Thermal and alternating field demagnetizations, b) measurements of continuous thermomagnetic curves (low field susceptibility versus temperature), and c) hysteresis experiments. 


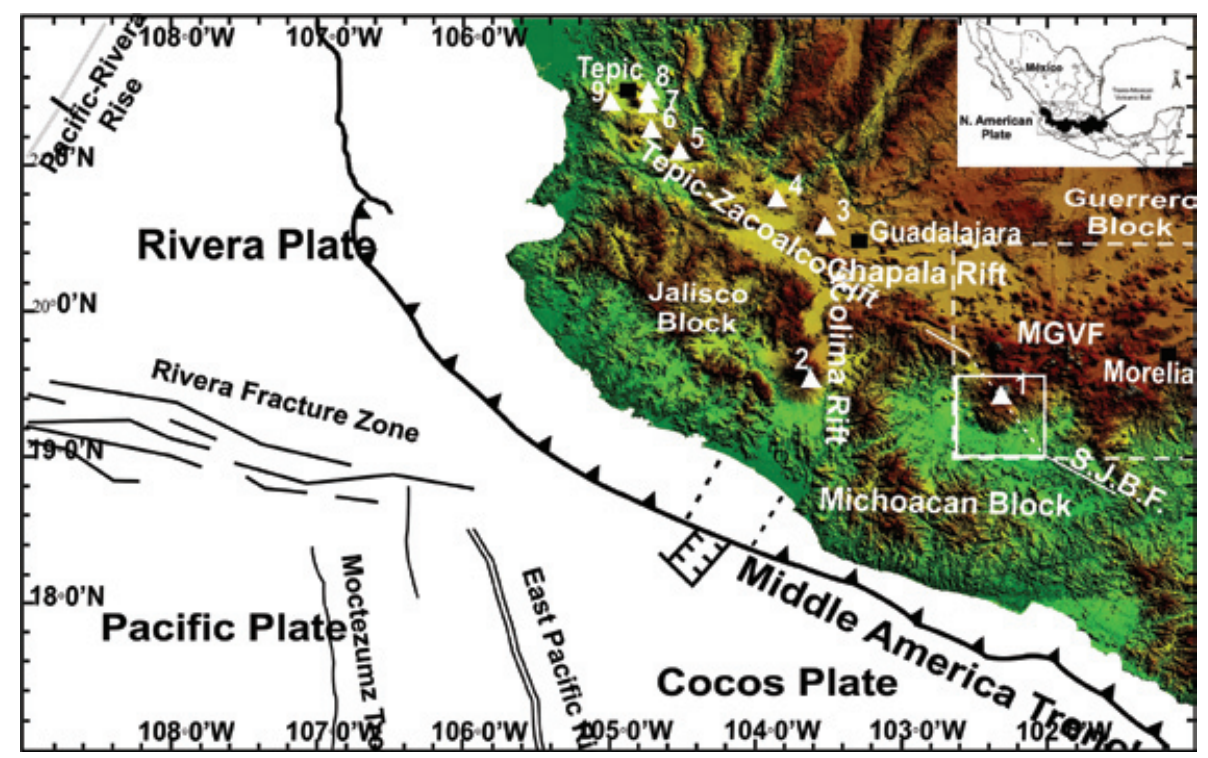

Fig. 1. Tectonic setting of western Mexico, adopted from Delgado-Granados (1993) and Ownby et al. (2007). Numbered triangles refer to volcanic centers: (1) V. Tancítaro, (2) V. Colima, (3) Sierra La Primavera, (4) V. Tequila, (5) V. Ceboruco, (6) V. Tepetiltic, (7) V. Sangangüey, (8) V. Las Navajas, (9) V. San Juan. S.J.B.F. = San Juanico-Bueanavista Fault. The dashed box represents the Michoacán Guanajuato Volcanic Field (MGVF).

\section{Table 1}

Flow-mean paleodirections of characteristic remanence, location and available isotopic age determinations (Ownby et al. 2007) for Tancitaro volcanics. N, number of treated samples; $n$, number of specimens used for calculation; Inc, Inclination; Dec, Declination; $\mathrm{k}$ and $\alpha_{95}$ : precision parameter and radius of 95\% confidence cone of Fisher statistics.

\begin{tabular}{|c|c|c|c|c|c|c|c|c|}
\hline Site & $\mathbf{n} / \mathbf{N}$ & $\operatorname{Inc}\left(^{\circ}\right)$ & $\operatorname{Dec}\left({ }^{\circ}\right)$ & $\mathbf{k}$ & a95 & Lat $\left({ }^{\circ}\right)$ & Long $\left(^{\circ}\right)$ & Age (Ka) \\
\hline Tan1 (TV) & $3 / 9$ & 23.8 & 7.8 & 56 & 16.5 & N 19² $24^{\prime} 58.3^{\prime \prime}$ & W $102^{\circ} 18^{\prime} 17.5^{\prime \prime}$ & $209 \pm 41$ \\
\hline Tan2 (TV) & $8 / 8$ & 43.5 & 353.5 & 199 & 3.9 & idem & idem & $209 \pm 41$ \\
\hline Tan3 (UR-4) & $8 / 8$ & 60.9 & 339.9 & 242 & 3.6 & N 19²2' 27.7' & W $102^{\circ} 05^{\prime} 03.3^{\prime \prime}$ & $429 \pm 64$ \\
\hline Tan4 (San Fco) & $0 / 8$ & - & - & - & - & N $19^{\circ} 22^{\prime} 08.8^{\prime \prime}$ & $\mathrm{W} 102^{\circ} 21^{\prime} 54.2^{\prime \prime}$ & $339 \pm 23$ \\
\hline Tan5 (Tan 28) & $2 / 8$ & 41.2 & 348.5 & - & - & N $19^{\circ} 23^{\prime} 40.2^{\prime \prime}$ & $\mathrm{W} 102^{\circ} 24^{\prime} 43.8^{\prime \prime}$ & $269 \pm 22$ \\
\hline Tan6 (Tan 26) & $7 / 8$ & 58.6 & 17.9 & 41 & 9.6 & N $19^{\circ} 25^{\prime} 32.6^{\prime \prime}$ & W $102^{\circ} 26^{\prime} 07.9^{\prime \prime}$ & $256 \pm 18$ \\
\hline $\operatorname{Tan} 7(\operatorname{Tan} 10)$ & $6 / 8$ & 28.1 & 348.6 & 115 & 6.3 & N $19^{\circ} 18^{\prime} 32.0^{\prime \prime}$ & W $102^{\circ} 32^{\prime} 22.5^{\prime \prime}$ & $373 \pm 61$ \\
\hline Tan8 (Tan 43') & $8 / 8$ & 27.7 & 2.5 & 359 & 2.9 & N $19^{\circ} 15^{\prime} 42.7^{\prime \prime}$ & W 102 33' 50.6" & $612 \pm 41$ \\
\hline $\operatorname{Tan} 9(\operatorname{Tan} 43)$ & $8 / 8$ & 31.3 & 352.7 & 39 & 9.2 & N $19^{\circ} 16^{\prime} 05.5^{\prime \prime}$ & W $102^{\circ} 34^{\prime} 08.44^{\prime \prime}$ & $612 \pm 41$ \\
\hline Tan10 (NI 19) & $7 / 8$ & 32.8 & 1.2 & 69 & 7.3 & N 1909'52.4" & W $102^{\circ} 12^{\prime} 56.7^{\prime \prime}$ & $82 \pm 24$ \\
\hline Tan11 (NI 18) & $7 / 8$ & 43.6 & 349.3 & 198 & 4.3 & N $19^{\circ} 00^{\prime} 36.9^{\prime \prime}$ & W $102^{\circ} 04^{\prime} 03.5^{\prime \prime}$ & $163 \pm 37$ \\
\hline
\end{tabular}




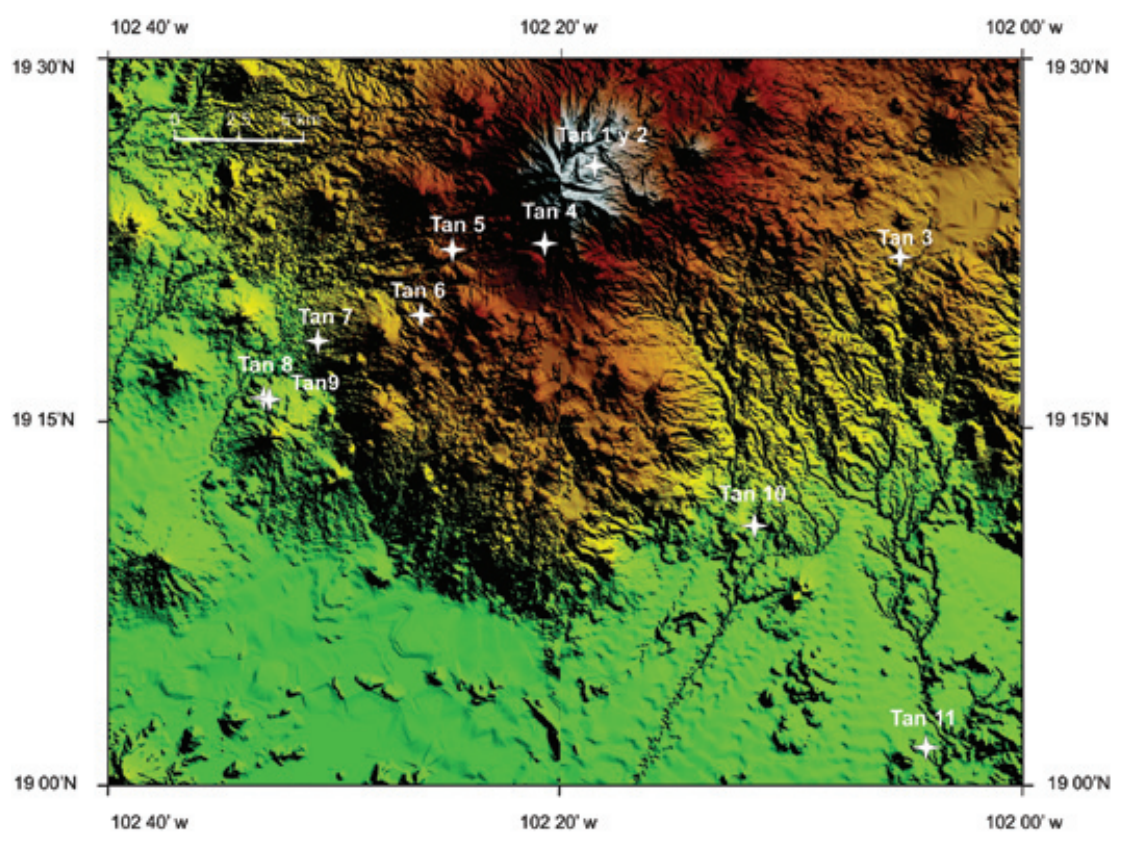

Fig. 2. Digital elevation model for Tancitaro area showing the location of sites.
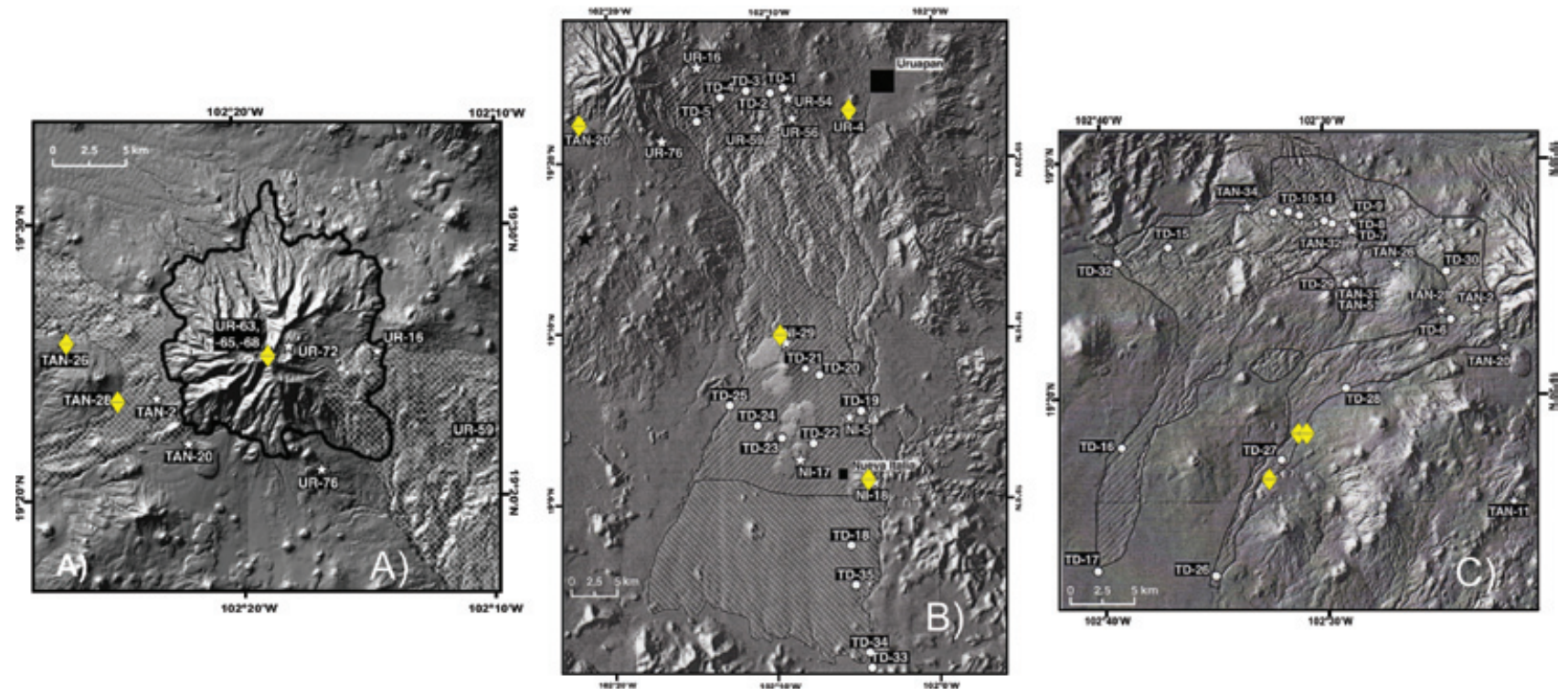

Fig. 3. Greater details of sampled site location (adopted from Ownby et al. 2007).

\section{Remanence Properties}

The remanent magnetizations of seven to nine samples from each lava flow (Table 1) were measured with a JR-6 (AGICO LtD) spinner magnetometer (nominal sensitivity $\left.\sim 10^{-9} \mathrm{Am}^{2}\right)$ at the Laboratorio Interinstitucional de Magnetismo Natural (LIMNA) in Morelia (Mexico). Both alternating field (AF) demagnetization (using a molspin AF-demagnetizer) and stepwise thermal demagnetization up to $560^{\circ} \mathrm{C}$ (using a $A S C T D-48$ furnace) were carried out. During thermal demagnetization, the low-field susceptibility at room temperature was measured after each step with a Bartington susceptibility meter. 
Two-component magnetizations were systematically recognized for most of studied units (Fig. 4). The secondary components are sometimes much stronger than primary ones (samples 08T012A, 08T012B and 08T093A). The characteristic magnetizations components are isolated after applying $40 \mathrm{mT}$ peak alternating field. It should be noted that $\mathrm{AF}$ treatments proved to be more efficient than thermal demagnetization. This is illustrated at Fig. 4. Samples 08T012B and 08T012A belong to the same core. While thermal treatment is unable to isolate primary remanence, the alternating fields could reveal the primary, characteristic magnetization at last steps of demagnetization procedure. We believe that the origin of this strong secondary overprint is due to the lightning effect. This is in agreement with the fact that the NRM (natural remanent magnetization) directions show huge dispersion on the equal-area projection. We note that no ChRM directions were obtained from sites TAN1, TAN4 and TAN5.

For remaining sites, relatively small, secondary components, probably of viscous origin were detected and were easily removed applying $10 \mathrm{mT}$ (Fig. 4, sample 08T107A). The greater part of remanent magnetization, in most cases was removed at temperatures between 520 and $560^{\circ} \mathrm{C}$, which indicate to low-Ti titanomagnetites as responsible for magnetization. The median destructive fields (MDF) range mostly from 20 to $40 \mathrm{mT}$, suggesting pseudo-single domain grains as remanent magnetization carriers (Dunlop and Özdemir, 1997).

A characteristic magnetization direction was determined by the least squares method (Kirschvink, 1980), 4 to 10 points being taken in the principal component analysis for this determination. The obtained directions were averaged by unit and the statistical parameters calculated assuming a Fisherian distribution.

\section{Susceptibility vs. Temperature}

Low-field susceptibility measurements (k-T curves) under air were carried out using Agico-Kapabrdige susceptibility meter equipped with furnace in Saint Maur (France) IPGP laboratory. One sample from each site were heated up to about $630^{\circ} \mathrm{C}$ at a heating rate $20^{\circ} \mathrm{C} /$ min and then cooled at the same rate. Curie temperature was determined by the Prévot et al's (1983) method. Alternatively, low-temperature (from about $-185^{\circ} \mathrm{C}$ to room temperature) susceptibility was recorded using the same apparatus.

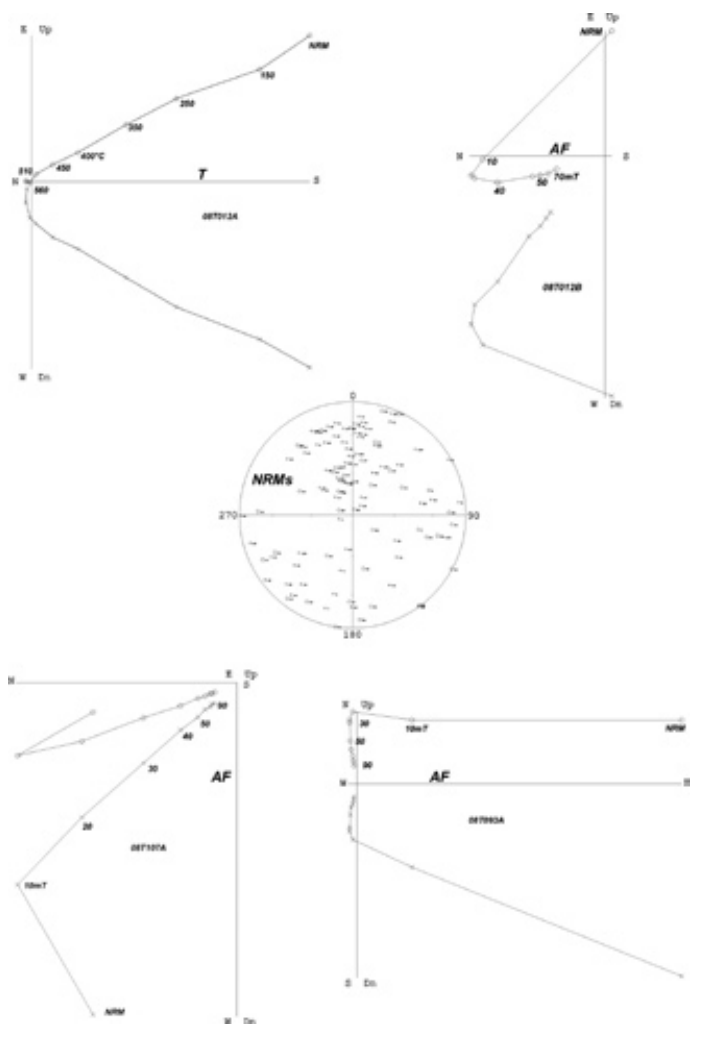

Fig. 4. Orthogonal vector plots of stepwise thermal or alternating field demagnetization of representative samples. The numbers refer either to the temperatures in ${ }^{\circ} \mathrm{C}$ or to peak alternating fields in $\mathrm{mT}$. o - projections into the horizontal plane, $\mathrm{x}$ - projections into the vertical plane. Also shown (middle) is the equal area projections of NRM directions before magnetic treatments. 
Low-T susceptibility experiments (Fig. 5) show a rather monotonic increase from about $-185^{\circ} \mathrm{C}$ to room temperature with no indication of Verwey transition. Some titanium-poor titanomagnetite may be responsible for remanent magnetization. As showed by Özdemir et al. (1993), the Verwey transition may be largely suppressed for the titanomagnetites with variable titanium content. Alternatively, similar behavior may also belong to non-stoichiometric (partially oxidized) magnetite. Corresponding high-T susceptibility experiments (Fig. 6) also indicate the presence of Ti-poor titanomagnetites. However, the cooling and heating curves are not perfectly reversible, probably because of low initial value of magnetic susceptibility. This may also be due to some moderate mineralogical alteration at high temperatures. Both Ti-rich and Ti-poor titanomagnetites seem to co-exist in few lava flows (samples 08T107 and 08T004A). These curve yields apparently two different thermomagnetic phases during heating. The lower Curie point ranges between $300-400^{\circ} \mathrm{C}$, while the highest one is about $570^{\circ} \mathrm{C}$.

\section{Hysteresis}

Magnetic hysteresis measurements were performed at room temperature on a specimen from all sampled sites at IPGP (Saint Maur) laboratory apparatus in fields up to 0.8 Tesla. The histeresis parameters were calculated after correction for the paramagnetic contribution. The coercivity of remanence $\left(\mathrm{H}_{\mathrm{cr}}\right)$ was determined by applying progressively increasing backfield after saturation. Typical hysteresis plot are reported in Fig. 7a. The representative curve is simple, symmetrical and reflects very restricted ranges of the coercivities (Tauxe et al., 1996). Judging from the ratios of hysteresis parameters (Fig. 7b), it seems that all samples fall in the pseudo-single domain (PSD) grain size region (Day et al., 1977). This may also indicate a mixture of multidomain (MD) and a significant amount of single domain (SD) grains (Dunlop and Özdemir, 1997; Dunlop, 2002).

\section{Results and discussion}

Beside strong lightning effect, the average unit directions are rather precisely determined for 8 independent lava flows out of 11 collected (Table 1, Fig. 8a). All $\alpha_{95}$ are less than $10^{\circ}$. All flows yielded normal polarity magnetization as may be expected for the Bruhnes age rocks. We consider the paleodirections determined in this study to be of primary origin. Thermomagnetic curves show that the remanence is carried in most cases by Ti-poor titanomagnetite, resulting of oxy-exsolution of original titanomagnetite during the initial flow cooling, which indicates that the primary magnetization is a TRM (thermoremanent magnetization). Moreover, unblocking temperature spectra and relatively high coercivities point to pseudo-single domain magnetic structure grains as responsible for remanent magnetization. The mean paleodirection obtained from eight flows is $\mathrm{Inc}=39.5^{\circ}$, Dec $=356.4^{\circ}, \mathrm{k}=29, \alpha_{95}=9.1^{\circ}$ which corresponds to the pole position Plat $=84.4^{\circ}$, Plong $=219.9^{\circ}, \mathrm{K}=33$ and $\mathrm{A}_{95}=8.5^{\circ}$. These directions are practically undistinguishable (Fig. $8 \mathrm{a}$ and $\mathrm{b}$ ) from both the spin axis and the expected PlioQuaternary paleodirections, as derived from reference poles for the North American craton (Besse and Courtillot, 2002). This may indicates that no major regional tectonic rotation occurred in the area since about $1 \mathrm{My}$. The mean inclination overlaps within the uncertainties to those derived from the GAD (Geomagnetic Axial Dipole) and GAD plus a $5 \%$ quadrupolar contributions.

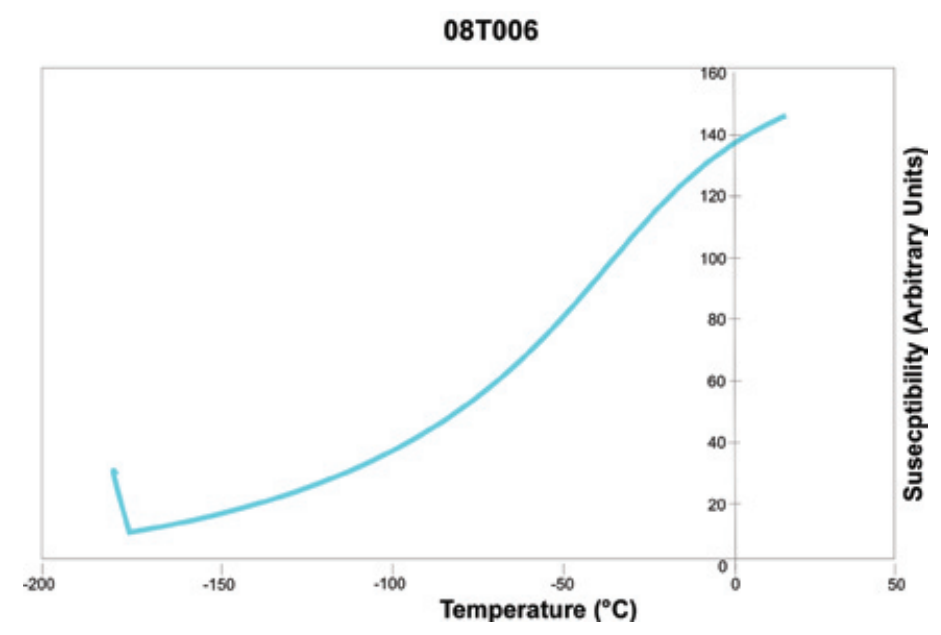

Fig. 5. representative curve of susceptibility vs. temperature curve recorded from $-185^{\circ} \mathrm{C}$ to room temperature. 

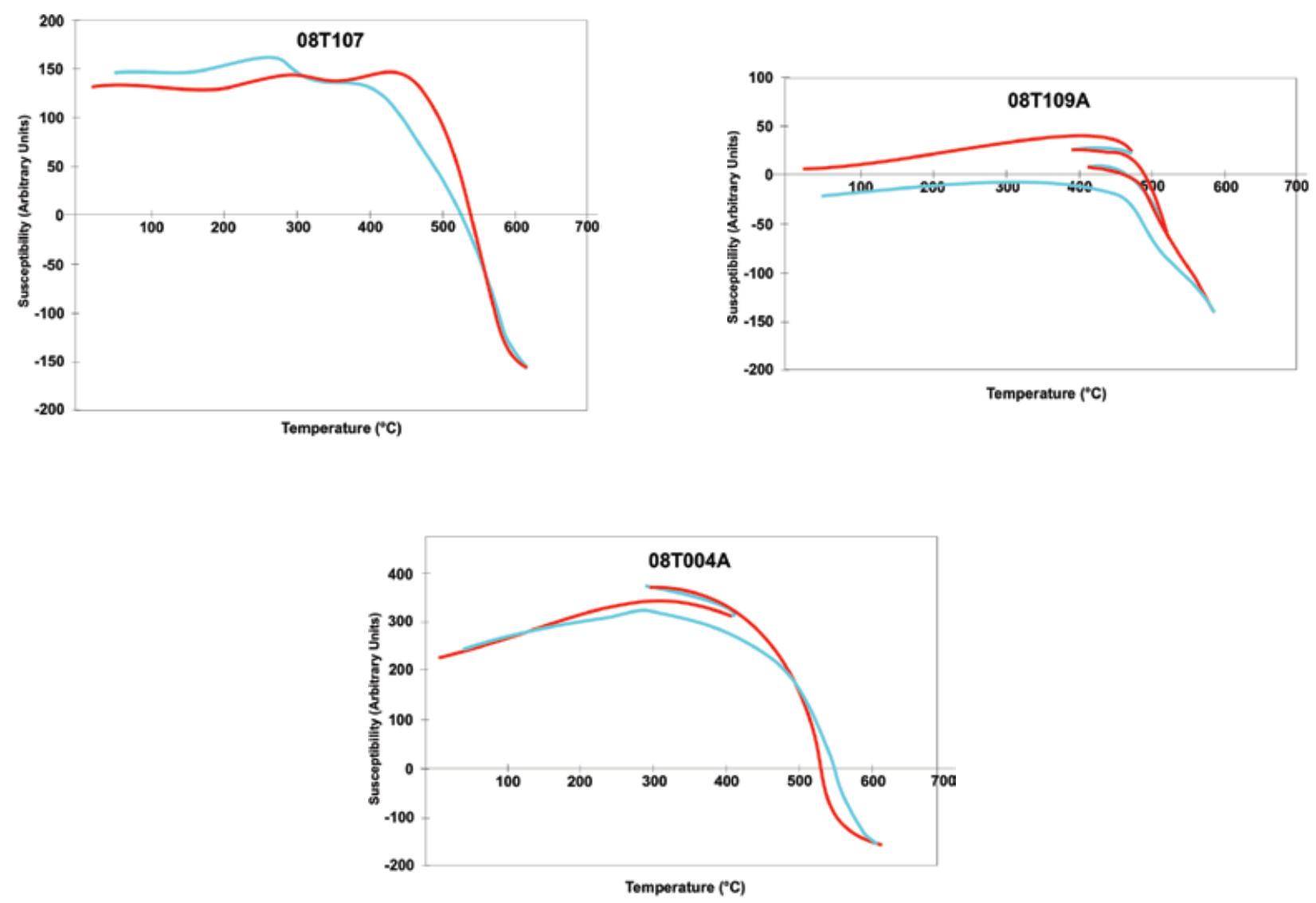

Fig. 6. Susceptibility versus temperature (in air) curves of representative samples at high temperatures.
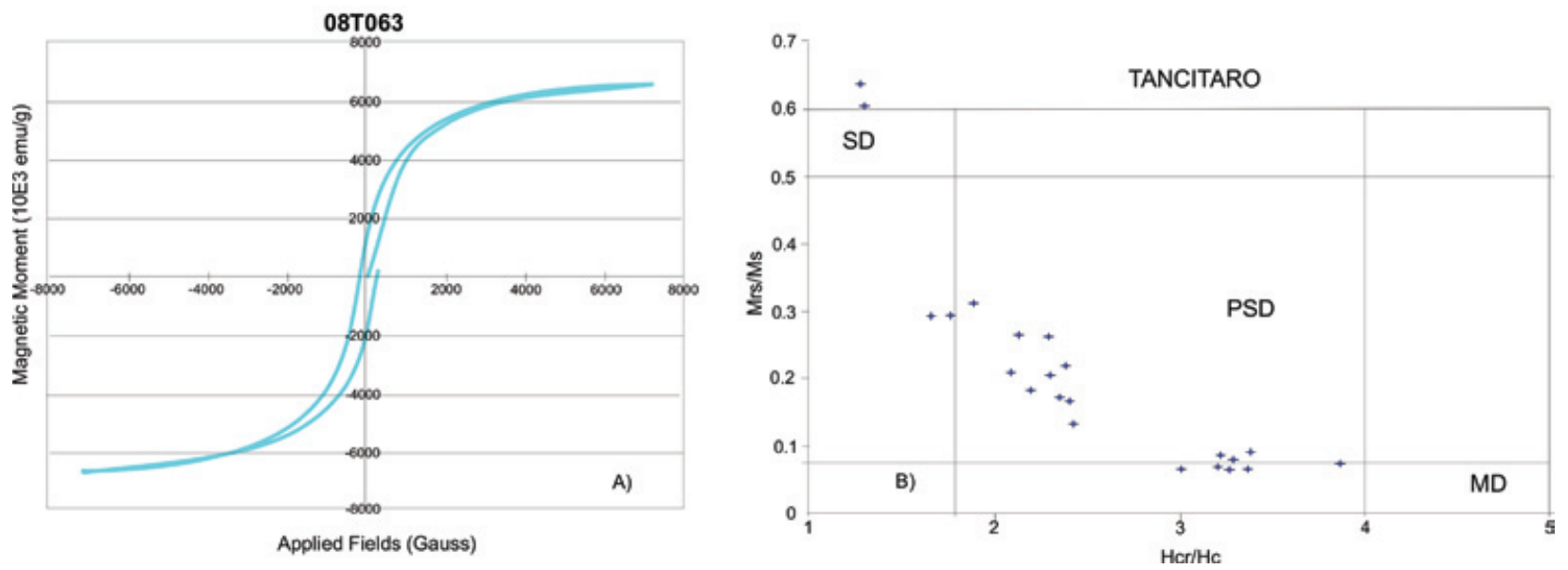

Fig. 7. Typical examples of hysteresis loops (uncorrected) and Day (Day et al. 1977) plot. 
The formula $S_{F}^{2}=S_{T}^{2}-S_{W}^{2} / n$ was used for estimating paleosecular variation in this study where, $S_{T}$ is the total angular dispersion $S_{T}=\left[(1 / \mathrm{N}-1) \sum_{i=1}^{N} \delta i^{2^{1 / 2}}\right][C o x, 1969], \mathrm{N}$ the number of sites used in the calculation, $\delta_{i}$ the angular distance of the $i$ th virtual geomagnetic pole (VGP) from the axial dipole, $S_{W}$ the within site dispersion (following McEllhinny and McFadden, 1997) and, $n$ the average number of sample per site. All new VGPs obtained on this study yield lesser colatitudes (maximum value is $28.3^{\circ}$ ) than generally adopted $45^{\circ}$ cut-off angle (Johnson et al., 2008). We obtained $S_{F}=16.0$ with $S_{U}=25.5$ and $S_{L}=8.1$ (upper and lower limits respectively) which reasonably agree to the model $\mathrm{G}$ of McFadden et al. $(1988,1991)$ fit to the McElhinny and McFadden (1997) and Johnson et al. (2008) databases for the last 5 Myr (Fig. 8b and 9).
The combination of our data with previously published results from Central and Western Mexico (Conte, 2004) yields that the amplitude of the secular variation is consistent with values obtained from other worldwide scattered sites. Thus, the hypothesis of the Pacific dipole window (Doell and Cox, 1971) may be rejected. This supports the findings of McElhinny et al. (1996) and Ruiz-Martínez, (2004). Within the uncertainties, the results obtained in this study agree with the PSV values for Hawaii $\left(+20^{\circ}\right.$ latitude) and Reunion $\left(-20^{\circ}\right.$ latitude). However, the amplitude of dispersion found is much higher in Mexico with respect to other places at the same latitude bands in agreement with findings of Lawrence $e t$ al., 2006. More high quality studies and reevaluation of old sites are needed in order to estimate whether this is a genuine characteristic of geomagnetic field.
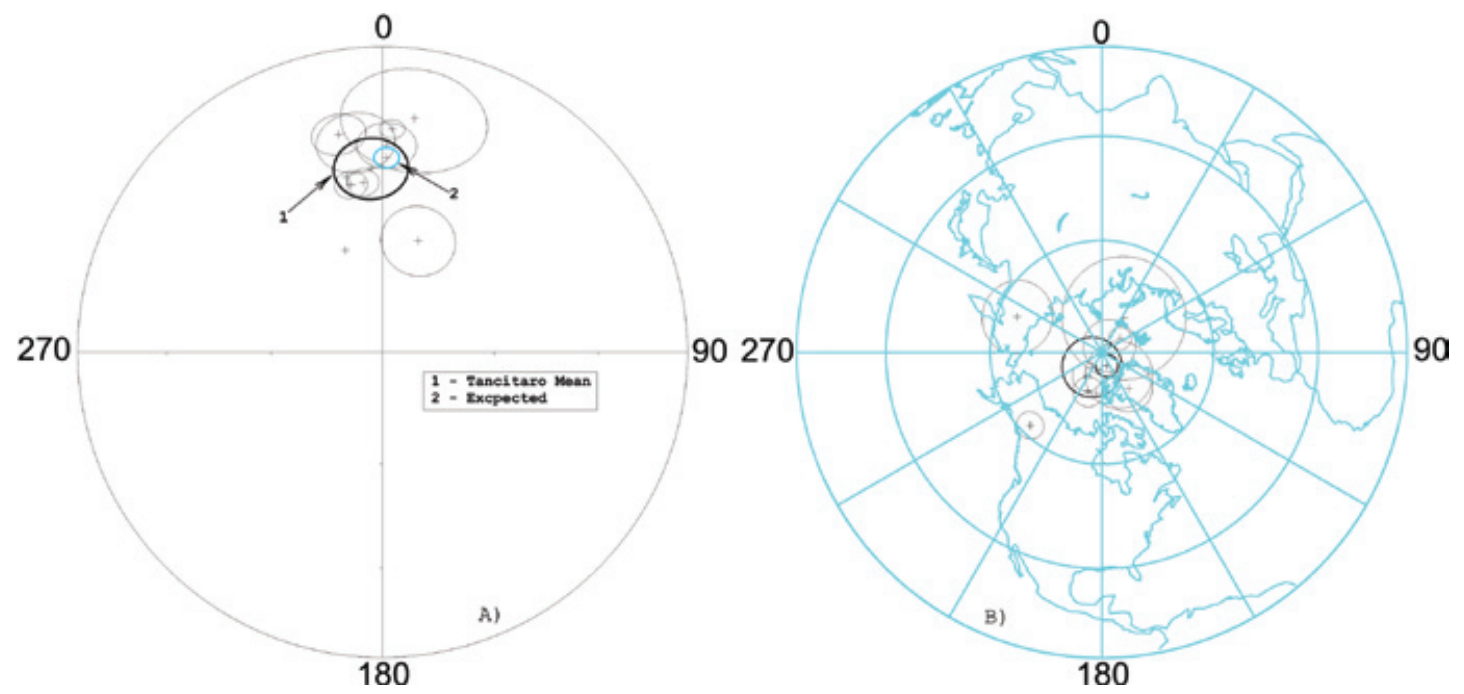

Fig. 8. A) Equal area projections of the flow-mean characteristic paleodirections for the Tancitaro volcanics and B) corresponding virtual geomagnetic pole positions.
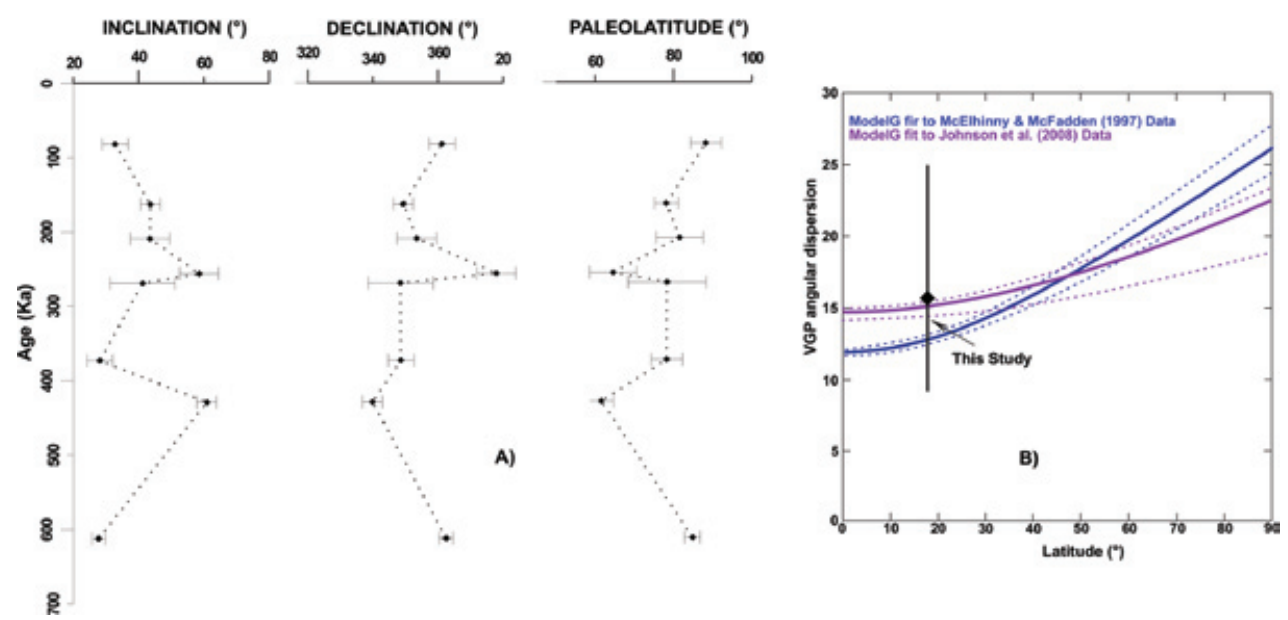

Fig. 9. A) Flow-mean magnetic declination, inclination and paleolatitude of virtual geomagnetic poles against age, B) Paleosecular variation of lavas (PSVL) for the last 5 Ma. (Adopted from McFadden et al., 1988 and 1991 and Johnson et al. 2008). 


\section{Acknowledgements}

This study was supported by UNAM-DGAPA grant $n^{\circ} 102007$ CONACYT grant $n^{\circ} 54957$. We thank Bernard Henry and Maxim le Goff for help during rock-magnetic measurements in Saint Maur. VCRM is grateful to the financial support given by MEC (Spain) "José Castillejo Program" ref. JC2007-00314.

\section{Bibliography}

Alva-Valdivia L. M, A. Goguitchaichvili and J. UrrutiaFucugauchi, 2001. Further Constraints for the PlioPleistocene Geomagnetic Field Strength: new results from Los Tuxtlas volcanic field (Mexico). Earth, Planets and Space 53, 9, 873-881.

Besse, J. and V. Courtillot, 2002. Apparent and true polar wander and the geometry of the geomagnetic field over the last 200 Myr. J. Geophys. Res., 107, B11, 1029/2000JB000050.

Conte, G., 2004. Estudio integrado de rocas volcánicas Plio-Cuaternarias de México y Italia, PhD Thesis, National University of México, 154pp.

Cox, A., 1969. Confidence limits for the precision parameter k. Geophys. J. R. astr. Soc. 18, 545-549.

Day, R., M. Fuller and V. A. Schmidt, 1977. Hysteresis properties of titanomagnetites: grain size and compositional dependence. Phys. Earth Planet. Int., 13, 260-267.

Delgado-Granados, H., 1993. Late Cenozoic tectonics offshore western Mexico and its relation to the structure and volcanic activity in the western TransMexican volcanic belt. Geofisica Internacional 32, 543-559.

Doell, R. and A. Cox, 1971. Pacific geomagnetic secular variation. Science, 71, 248-254.

Dunlop, D. and Ö. Özdemir, 1997. Rock magnetism: fundamentals and frontiers, Cambridge University Press, 573 pp.

Dunlop, D., 2002. Theory and application of the Day plot $\left(\mathrm{M}_{\mathrm{rs}} / \mathrm{M}_{\mathrm{S}}\right.$ versus $\left.\mathrm{H}_{\mathrm{cr}} / \mathrm{H}_{\mathrm{C}}\right)$ 1. Theoretical curves and tests using titanomagnetite data. J. Geophys. Res., 107, 10.1029/2001JB000486.

Johnson, C. L., C. G. Constable, L. Tauxe, R. W. Barendregt, L. L. Brown, R. S. Coe, P. Layer, V.
Mejia, N. D. Opdyke, B. S. Singer, H. Staudigel, and D. Stone, 2008. Recent investigations of the 0-5 ma geomagnetic field recorded in lava flows. Geochemistry, Geophysics, Geosystems, 9:Q04032, doi:10.1029/2007GC001696.

Hasenaka, T., 1994. Size, distribution, and magma output rate for shield volcanoes of the Michoacán-Guanajuato volcanic field, Central Mexico. Journal of Volcanology and Geothermal Research, 63, 13-31.

Hasenaka, T., M. Ban and H. Delgado-Granados, 1994. Contrasting volcanism in the Michoacán-Guanajuato Volcanic Field, central Mexico: Shield volcanoes vs. cinder cones. Geofisica Internacional, 33, 1, 125138.

Herrero-Bervera E., J. Urrutia-Fucugauchi, A. Martin del Pozzo, H. Bohnel and J. Guerrero, 1986. Normal amplitude Brunhes paleosecular variation at lowlatitudes: A paleomagnetic record from the TransMexican Volcani Belt. Geophysical Research Letters, 13, 1442-1445.

Kirschvink, J. L. 1980. The least-square line and plane and analysis of palaeomagnetic data. Geophys. J. R. Astron. Soc., 62, 699-718.

Klitgord, K. D. and J. Mammerickx, (1982). Northern East Pacific Rise-Magnetic anomaly and bathymetric framework. J. Geophys. Res., 87, 6725-6783.

Lawrence, K. P., C. G. Constable, C. L. Johnson, 2006. Paleosecular variation and the average geomagnetic field at $\pm 20^{\circ}$ latitude. Geochem. Geophys. Geosyst., doi:10.1029/2004GC000871.

Lawrence, K. P., L. Tauxe, H. Staudigel, C. G. Constable, A. Koppers, W. McIntosh and C. L. Johnson, 2009. Paleomagnetic field properties near the southern hemisphere tangent cylinder. Geochem. Geophys. Geosys., 10, Q01005, doi:10.1029/2008GC002072.

McEllhinny, M. W., P. L. McFadden and R. Merrill, 1996, The myth of the Pacific dipole window. Earth Planet Sci. Lett., 143,13-22.

McElhinny, M. W. and P. L. McFadden, 1997. Palaeosecular variation over the past $5 \mathrm{Myr}$ based on a new generalized database. Geophys. J. Int., 131, 240-252.

McFadden, P., T. Merrill and W. McElhinny, 1988, Dipole/Quadrupole Family Modeling of Paleosecular 
Variation. Journal of Geophysical Research, 93, 11,583-11,588.

McFadden, P. L., R. Merrill, M. W. McEllhinny and S. Lee, 1991. Reversals of the Earth's magnetic field and temporal variations of the dynamo families. $J$. Geophys. Res., 96, 3923-3933.

Mejia, V., H. Bohnel, M. A. Ortega-Rivera, J. Lee and J. Aranda-Gomez, 2005. Paleosecular variation and timeaveraged field recorded in Late Pliocene-Holocene lava flows from Mexico. Geochem. Geophys. Geosyst., 6, doi : 10.1029/2004GC000871.

Morales, J.,A. Goguitchaichvili and J.Urrutia-Fucugauchi, 2001. A rock-magnetic and paleointensity study of some Mexican volcanic lava flows during the Latest Pleistocene to the Holocene. Earth Planets Space, 53, 839-902.

Osete, M. L., V. C. Ruiz-Martinez, C. Caballero, C. Galindo, J. Urrutia-Fucugauchi and D. Tarling, 2000, Southward migration of continental volcanic activity in the Sierra de Las Cruces, Mexico: Palaeomagnetic and radiometric evidence. Tectonophysics, 318, 201215.

Ozdemir, O., D. Dunlop and B. M. Moskowitz, 1993. The effect of oxidation on the Verwey transition in magnetite. Geophys. Res. Lett., 20, 1671-1674.

Ownby, S. E., H. Delgado-Granados, R. A. Lange and C. M. Hall, 2007. Volcan Tancitaro, Michoacan, Mexico, 40ar/39ar constraints on its history of sector collapse. J. Volcanology and Geothermal Res., 161, 1-14.

Petronille, M., A. Goguitchaichvili, B. Henry, L. AlvaValdivia, J. Rosas-Elguera, M. Rodríguez Ceja and M. Calvo-Rathert, 2005. Paleomagnetism of Ar-Ar dated lava flows from the Ceboruco-San Pedro volcanic field (western Mexico): Evidence for the MatuyamaBrunhes transition precursor and a fully reversed geomagnetic event in the Brunhes chron. J. of Geophys. Res., 110, b08101, doi:10.1029/2004jb003321.

Prévot, M., E. A. Mankinen, S. Grommé and A. Lecaille, 1983. High paleointensities of the geomagnetic field from thermomagnetic study on rift valley pillow basalts from the mid-Atlantic ridge. J. Geophys. Res., 88, 2316-2326.

Rodriguez-Ceja, M., A. Goguitchaichvili, M. CalvoRathert, J. Morales-Contreras, L. Alva-Valdivia, J. R. Elguera, J. U. Fucugauchi and H. D. Granados, (2006).
Paleomagnetism of Tequila Volcanic Field: Western Mexico. Earth Planets Space, 58, 10, 1349-1358.

Ruiz-Martinez, V. C., M. L. Osete, R. Vegas, J. I. Nunez- Aguilar, J. Urrutia-Fucugauchi and D. H. Tarling, 2000. Palaeomagnetism of Late Miocene to Quaternary volcanics from the eastern segment of the Trans-Mexican Volcanic Belt. Tectonophysics, 318, 217-233.

Ruiz-Martínez, V. C., 2004. Estudio paleomagnético del cinturón volcánico transmexicano: implicaciones tectónicas, $\mathrm{PhD}$ thesis, Universidad Complutense de Madrid, ISBN 84-669-1761-6, 288 pp., Madrid.

Tauxe, L., T. A. T. Mullender and T. Pick, 1996. Pot-bellies, wasp-waists and superparamagnetism in magnetic hysteresis. J. Geophys. Res., 95, 12337-12350.

Tauxe, L., C. Luskin, P. Selkin, P. Gans and A. Calvert, 2004. Paleomagnetic results from the Snake River Plain: Contribution to the time-averaged field global database. Geochem. Geophys. Geosyst., 5, Q08H13, doi:10.1029/2003GC000661.

R. Maciel Peña ${ }^{1 *}$ A. Goguitchaichvilii ${ }^{1}$ V. Hugo Garduño Monroy², V. Carlos Ruiz Martinez $^{3}$, B. Aguilar Reyes ${ }^{1}$, J. Morales ${ }^{1}$, L. Alva-Valdivia $^{4}$, C. Caballero Miranda ${ }^{4}$ and J. Urrutia-Fucugauchi ${ }^{4}$

${ }^{1}$ Laboratorio Interinstitucional de Magnetismo Natural, Instituto de Geofísica, Sede Michoacán, Universidad Nacional Autónoma de México, Campus Morelia, Mexico.

${ }^{2}$ Departamento de Geología y Mineralogía, Instituto de Investigaciones Metalúrgicas, Universidad Michoacana, San Nicolás de Hidalgo, Morelia, Michoacán, Mexico.

${ }^{3}$ Departamento de Física de la Tierra, Astronomía y Astrofísica I, Universidad Complutense de Madrid, 28040, Madrid, Spain

${ }^{4}$ Laboratorio de Paleomagnétismo y Geofísica Nuclear, Instituto de Geofísica, Universidad Nacional Autónoma de México, Ciudad Universitaria, Del Coyoacán 04510 México City, Mexico

*Corresponding author: rafaelmacielmx@yahoo.com. $m x$ 